\title{
Development of E-learning Based on Augmented Reality (AR) on Reduction-Oxidation Reaction Topic
}

\author{
https://doi.org/10.3991/ijim.v16i03.28977 \\ Isnanik Juni Fitriyah ${ }^{(凶)}$, Muhammad Fajar Marsuki, Yessi Affriyenni \\ Faculty of Mathematics and Natural Sciences, Universitas Negeri Malang, Malang, Indonesia \\ isnanik.fitriyah. fmipa@um.ac.id
}

\begin{abstract}
The concept of electrochemistry is based on reduction-oxidation (redox) reactions and electrolyte solutions. Where this material is difficult to understand because the aspects studied include submicroscopic aspects. It takes teaching materials that are able to display animations of redox reactions. This study aims to develop teaching materials based on Augmented Reality on Redox Reaction material. This type of research includes research and development (R\&D) using the ADDIE model with the stages of analysis, design, develop and evaluation. The product will be tested for validity through expert testing and field testing. The validation test of material, media and readability experts to students resulted in a percentage of $92.5 \%, 94.39 \%$ and $91.6 \%$ respectively or declared very feasible and very good for use in lectures with several revisions. It can be concluded that, AR-based media is stated to be very feasible and very good for use in learning. It is hoped that further testing of the effectiveness of this media will be carried out.
\end{abstract}

Keywords-E-learning, redox reaction, augmented reality

\section{Introduction}

The industrial revolution 4.0 affects all aspects of life in the world. With this industrial revolution, the role of technological development is very high. Technology is not only targeting an industry, communication. Technology is becoming very common and often encountered in everyday life. From its own understanding, technology is a tool or product made to facilitate human work. Technology can be used in various fields, including education [1].

Technology in education is able to become the latest innovation with increased usefulness, increased attractiveness and increased efficiency [2]. Examples of forms of technology in education are the existence of devices for doubling learning resources, devices as learning resources to devices for more interesting teaching and learning processes. The use of technology in education can be in the form of learning media and teaching materials. In learning media, technology is not only a tool for distributing material but can provide and facilitate things that conventional learning media cannot do, such as Augmented Reality (AR) technology [3]. 
Augmented Reality (AR) technology is a technology that is able to provide a form of visualization of something through the process of scanning a real marker and then projecting it into the virtual world [4]. This technology has 2 main components in its use, namely markers and camera scanners. Augmented Reality (AR) technology has now become a technology that is often used in everyday life both for entertainment (games) or education. In the world of education, Augmented Reality technology is able to become an alternative media that can display microscopic material into a form that can be seen through devices [5]. Of course, with good planning, Augmented Reality technology can display interesting forms such as cartoons, animations or 3-dimensional shapes of the material in the lesson [6].

An example of the use of Augmented Reality technology in education is the development of teaching materials with the help of Augmented Reality on chemical bonding materials [7]. In this development, examples of chemical bonds can be described in the form of a three-dimensional molecule through scanning of the designed marker. The teaching materials with the help of Augmented Reality were also declared very feasible to be used in lectures. Another example of using Augmented Reality technology is in solar system teaching materials [8]. Augmented Reality is not only able to provide a clearer picture of microscopic things such as chemical bonds [9], but also something as broad as the solar system. The use of teaching materials for the solar system with the help of Augmented Reality is said by students to be more interesting because the principle of its use is like a game on a smartphone. Users are able to see the side of the AR scanned object from various sides. The addition of the Augmented Reality feature to the teaching materials made is also able to improve students' understanding of concepts [10] and students' 4C skills [11].

Based on observations and interviews conducted with students of the Science Education Study Program, in the Basic Chemistry II course, students experience boredom in learning, especially on redox reaction materials. This is because the teaching materials used are conventional teaching materials such as printed books, ebooks and learning videos. Moreover, during the current online learning period, students who study on their own through materials shared by lecturers experience a decline in their enthusiasm for learning. Redox reaction material itself is a material in which the study of the occurrence of oxidation and reduction reactions. The reduction and oxidation reactions taught in the book are in the form of chemical reactions written in chemical notation. This form of depiction requires students' ability to understand more concepts. To improve students' understanding of concepts and motivation in learning redox reactions, teaching materials are needed that are able to describe more interesting redox reactions. The technology that is able to describe this is Augmented Reality technology. Therefore, the purpose of this study is to develop teaching materials based on Augmented Reality on redox reaction materials that are suitable for use for students of the Science Education Study Program. 


\section{Method}

This type of research is included in research and development (R\&D). Research using the ADDIE development model by Lee \& Owens (2004). The steps taken are as follows:

\subsection{Analysis}

In the analysis stage, observations and interviews were carried out with students of the Science Education Study Program via Google Form. The data found that students experienced boredom in learning redox reactions with existing teaching materials.

\subsection{Design}

In the design stage, the media design is made in the form of Augmented Reality-based media. The preparation of storyboards of content, media and instruments needed in research is carried out.

\subsection{Development}

In the development stage, media is made, starting from the Redox Reaction book with markers in it and a marker scanner application that can be installed on a smartphone. Media validation tests were also carried out in terms of material, media and readability to students.

\subsection{Development}

In the evaluation stage, the feasibility of Augmented Reality-based media in Basic Chemistry lectures is carried out.

The research instrument used was the validation test instrument for material experts, media experts and readability to students of the Science Education Study Program. Research data in the form of qualitative and quantitative. The data analysis technique used descriptive analysis data analysis techniques. This technique will convert the results of the validation scores into percentages and then categorized them into categories of the feasibility level of the developed media. The categories are in accordance with Table 1.

Table 1. The category of feasibility level of the developed media [13]

\begin{tabular}{|c|c|l|}
\hline No & Percentage & \multicolumn{1}{c|}{ Category } \\
\hline 1 & $81 \%-100 \%$ & Very valid \\
\hline 2 & $61 \%-80 \%$ & Valid \\
\hline 3 & $41 \%-60 \%$ & Enough valid \\
\hline 4 & $21 \%-40 \%$ & Less valid \\
\hline 5 & $0 \%-39 \%$ & Invalid \\
\hline
\end{tabular}




\section{$3 \quad$ Results and discussion}

The use of teaching materials in the form of printed books, electronic books in pdf format or learning videos has become common and conventional learning materials for students. Sometimes, teaching materials like this can cause students to experience boredom in learning so that learning motivation will tend to decrease. This happened to students of the Science Education Study Program at the State University of Malang. This study aims to develop innovative teaching materials for students of the Science Education Study Program in the form of books based on Augmented Reality (AR) on Redox Reaction material.

\subsection{Development of augmented reality (AR) based teaching materials on redox reaction materials}

The teaching materials developed have 2 main products, namely books and applications. This book has A5 size specifications, full color pages, thick paper and there are markers in it. This teaching material contains a brief explanation of redox reactions, reduction reactions, oxidation reactions and examples of redox reactions. There are only two examples of redox reactions, namely the formation of magnesium oxide compounds and the formation of calcium sulfide compounds. An example of the appearance of the book can be seen in Figure 1.

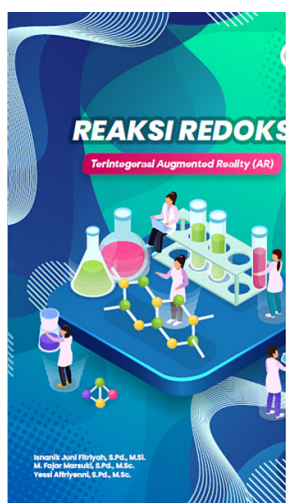

(a)

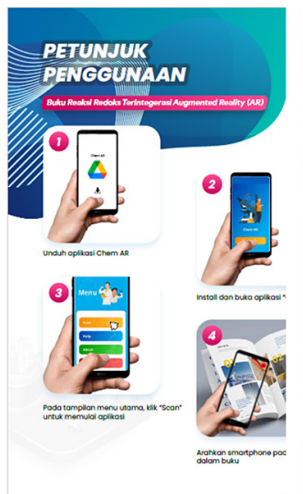

(b)

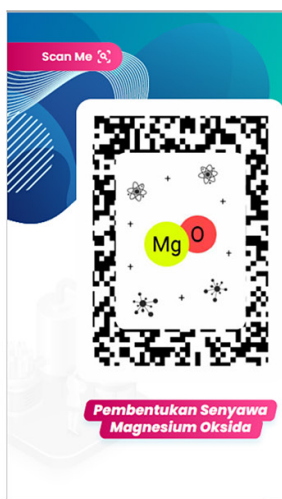

(c)

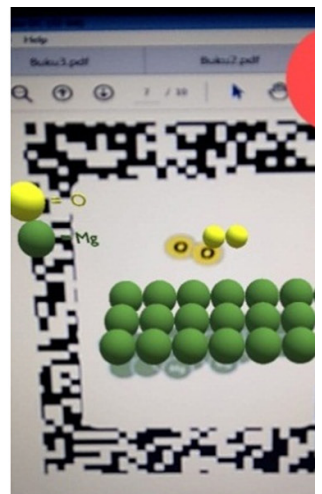

(d)

Fig. 1. Display of teaching materials; a) Book cover page, b) User manual page, c) Redox reaction sample page with markers, d) Augmented reality display

Based on Figure 1, it can be seen that the cover page of the developed book has full colors of blue and green shades. There is an animation of a person with various chemical tools. In the instructions for use, there are also steps for using the book with Augmented Reality accompanied by pictures. In the redox reaction example section, there is a "Scan Me" sign as a sign to the user that the page can be scanned with the installed smartphone application. So, the display when scanned will look like in picture (d).

Tests for the feasibility of teaching materials were carried out twice, namely validation tests in terms of material content by material experts and validation tests in terms 
of media appearance by media experts. The data from the validation test results can be seen in Table 2.

Table 2. Material expert validation test results

\begin{tabular}{|c|l|c|}
\hline No & \multicolumn{1}{|c|}{ Rated Aspects } & Percentage (\%) \\
\hline 1 & Eligibility of book grammar & 83.33 \\
\hline 2 & Eligibility of presenting the contents of the book & 87.50 \\
\hline 3 & The truth of the book concept & 100 \\
\hline 4 & App grammar eligibility & 91.67 \\
\hline 5 & App concept correctness & 100 \\
\hline 6 & Amount & 462.5 \\
\hline 7 & Average percentage & 92.5 \\
\hline
\end{tabular}

Based on Table 2, the entire percentage of the material aspect is above $83 \%$ so that the average percentage is also high, the value is $92.5 \%$. This value means that teaching materials in terms of the content of the material are included in the very feasible category. In the aspect of the feasibility of presenting the contents of the book, there is a statement that learning with Augmented Reality is able to be a solution to the abstraction of the material for reduction and oxidation reactions to students. This is because so far examples of reduction and oxidation reactions have only been shown in teaching materials through a chemical reaction equation without students being able to see the actual form. With Augmented Reality, images of examples of reduction and oxidation reactions can be seen by students even through an animation. This is in line with research which states that moving images, videos or animations of an event are able to overcome students' difficulties in imagining abstract concepts of events [14], [15]. Some suggestions from the validator are adding examples of redox reactions and material development. The results of the validation test of teaching materials based on media experts can be seen in Table 3 .

Table 3. Media expert validation test results

\begin{tabular}{|c|l|c|}
\hline No & \multicolumn{1}{|c|}{ Rated Aspects } & Percentage (\%) \\
\hline 1 & Presentation of the front page of the book & 95.00 \\
\hline 2 & Instructions for use & 91.67 \\
\hline 3 & Table of contents & 91.67 \\
\hline 4 & Contents page & 93.75 \\
\hline 5 & Marker & 100.00 \\
\hline 6 & Application opening screen & 87.50 \\
\hline 7 & Main course & 90.00 \\
\hline 8 & Application button & 100.00 \\
\hline 9 & Marker scan & 100.00 \\
\hline & Amount & 849.59 \\
\hline & Average percentage & 94.39 \\
\hline
\end{tabular}


Based on Table 3, the entire percentage of the material aspect is above $87 \%$ so that the average percentage is also high, the value is $94.39 \%$. This value means that teaching materials in terms of media appearance are included in the very feasible category. For the readability test to 30 students, it has an average percentage result of $91.6 \%$. This means that the display of teaching materials for students is very good and smooth.

\subsection{Use of augmented reality (AR) based teaching materials in basic chemistry II lectures}

Augmented Reality-based teaching materials contain redox reaction materials. This teaching material is in the form of a printed book equipped with instructions for use and markers in it. Instructions for use are made as a guide for users or readers in using printed books so that they not only use them by reading, but also operate applications for the marker scanning process. Based on the response test to students, the instructions for use are very clear and easy to understand so that the use of this book is also quite easy.

The marker of the redox reaction sample consisted of two markers, both of which passed the material and media validation tests. This indicates that the marker display is good and the marker scanning process is also running smoothly. The markers here have been prepared and designed by the developer to show examples of the shape of a redox reaction. Thus, the display of redox reactions in this book is not only an image of a chemical reaction with chemical notation but also includes colorful moving animations witnessed on a smartphone screen [16]. Students admitted that this kind of display is a new and more interesting display when compared to examples of redox reactions in conventional printed books.

During the online learning period, lectures are carried out in full through the Learning Management System (LMS) [17]. At the State University of Malang, lectures are conducted through the campus e-learning platform called SIPEJAR. By providing innovative teaching materials to students, it can increase students' interest and motivation to learn which is starting to decline. Therefore, the results of the development of these teaching materials can be given to students during online learning by sending a Google Drive link from a PDF of the book along with a Google Drive link from the application on the SIPEJAR platform page for Basic Chemistry II course. So, even though students cannot meet the lecturers in class to share or use this book directly, students can still use it at home using the soft files of this book. This is one of the advantages and conveniences of technology-based teaching materials.

\section{Conclusion}

Augmented Reality (AR)-based teaching materials have been developed in the form of books with Redox Reaction materials accompanied by applications installed on smartphones. Teaching materials are included in the appropriate category for use based on the results of the validation test of material, media and readability experts. The use of Augmented Reality-based teaching materials in lectures is able to provide the latest innovations in the world of education and can increase student interest in learning. 


\section{$5 \quad$ Acknowledgment}

Many thanks are expressed to the State University of Malang PNBP as a provider of funds to support the implementation of the research. Thanks also to all parties, members of the authors who helped complete the research until writing. Also thanks to the students of the Science Education Study Program as research subjects.

\section{References}

[1] A. A. Shahroom and N. Hussin, 'Industrial Revolution 4.0 and Education', Int. J. Acad. Res. Bus. Soc. Sci., vol. 8, no. 9, pp. 314-319, 2018, doi: https://doi.org/10.6007/IJARBSS/ v8-i9/4593

[2] M. S. Rasul, R. A. A. Rauf, A. N. Mansor, and H. M. Affandi, 'Using QR-Code in A Green Technology Module to Foster Motivation and Independent Learning', Int. J. Innov. Learn., vol. 22, no. 2, pp. 177-197, 2017. https://doi.org/10.1504/IJIL.2017.085920

[3] M. E. Ismail et al., 'The Effect of an Augmented Reality Teaching Kit on Visualization, Cognitive Load and Teaching Styles', J. Pendidik. Teknol. dan Kejuru., vol. 24, no. 2, pp. 178-184, 2018, doi: https://doi.org/10.21831/jptk.v24i2.20031

[4] M. Gattullo, G. W. Scurati, M. Fiorentino, A. E. Uva, F. Ferrise, and M. Bordegoni, 'Towards Augmented Reality Manuals for Industry 4.0: A Methodology', Robot. Comput. Integr. Manuf., vol. 56, pp. 276-286, 2019, doi: https://doi.org/10.1016/j.rcim.2018.10.001

[5] J. Martin, J. Bohuslava, and H. Igor, 'Augmented Reality in Education 4.0', in IEEE 13th International Scientific and Technical Conference on Computer Sciences and Information Technologies, CSIT 2018 - Proceedingstion Technologies, CSIT 2018 - Proceedings, vol. 1, pp. 231-236, 2018, doi: https://doi.org/10.1109/STC-CSIT.2018.8526676

[6] R. D. A. Budiman, 'Developing Learning Media Based on Augmented Reality (AR) To Improve Learning Motivation', JETL (Journal Educ. Teach. Learn., vol. 1, no. 2, p. 89, 2016, doi: https://doi.org/10.26737/jetl.v1i2.45

[7] I. J. Fitriyah, A. M. Setiawan, M. F. Marsuki, and E. Hamimi, 'Development of Augmented Reality Teaching Materials of Chemical Bonding', in AIP Conference Proceedings, 2021, vol. 2330, doi: https://doi.org/10.1063/5.0043235

[8] I. N. Q. Aini, A. Triayudi, and I. D. Sholihati, 'Aplikasi Pembelajaran Interaktif Augmented Reality Tata Surya Sekolah Dasar menggunakan Metode Marker Based Tracking', J. Media Inform. Budidarma, vol. 4, no. 1, pp. 178-184, 2020, doi: https://doi.org/10.30865/mib. $\underline{\mathrm{v} 4 \mathrm{i} 1.1875}$

[9] I. J. Fitriyah, A. M. Setiawan, M. F. Marsuki, and E. Hamimi, 'Development of Augmented Reality Assisted Learning Media to Improve Concept Understanding of Chemical Bonding Topics', J. Pembelajaran Sains, vol. 4, no. 1, pp. 61-66, 2020, doi: $10.17977 /$ um033v4i2p61-66

[10] Y. Affriyeni, G. Swalaganata, V. R. Mustikasari, and I. J. Fitriyah, 'Pengembangan Media Pembelajaran Fisika pada Materi Optik Geometri Berbasis Augmented Reality dengan Unity dan Vuforia', JIPVA (Jurnal Pendidik. IPA Veteran), vol. 4, no. 2, pp. 160-174, 2020 , doi: https://doi.org/10.31331/jipva.v4i2.1301

[11] E. Elisa and I. G. Wiratmaja, 'Augmented Reality: Analisis Pengembangan Media Pembelajaran Kimia untuk Meningkatkan Keterampilan 4C Mahasiswa', J. Indones. Soc. Integr. Chem., vol. 11, no. 2, pp. 73-81, 2019. https://doi.org/10.22437/jisic.v11i2.8124

[12] W. W. Lee and D. L. Owens, Multimedia-Based Instructional Design, Second Edi. San Fransisco: Pfeiffer, 2004. 
[13] Hanafi, 'Konsep Penelitian R \& D dalam Bidang Pendidikan', Saintifika Islam. J. Kaji. Keislam., vol. 4, no. 2, pp. 129-150, 2017.

[14] R. A. Mashami and G. Gunawan, 'The Influence of Sub-Microscopic Media Animation on Students' Critical Thinking Skills Based on Gender', J. Phys. Conf. Ser., vol. 1108, no. 1, 2018, [Online]. Available: https://doi.org/10.1088/1742-6596/1108/1/012106

[15] I. Helsy, Maryamah, I. Farida, and M. A. Ramdhani, 'Volta-Based Cells Materials Chemical Multiple Representation to Improve Ability of Student Representation', J. Phys. Conf. Ser., vol. 895, no. 1, 2017. https://doi.org/10.1088/1742-6596/895/1/012010

[16] N. F. Saidin, N. D. A. Halim, and N. Yahaya, 'A Review of Research on Augmented Reality in Education: Advantages and Applications’, Int. Educ. Stud., vol. 8, no. 13, pp. 1-8, 2015, doi: https://doi.org/10.5539/ies.v8n13p1

[17] A. M. Setiawan, Munzil, and I. J. Fitriyah, 'Trend of Learning Management System (LMS) Platforms for Science Education Before-after Covid-19 Pandemic', AIP Conf. Proc., vol. 2330, no. March, pp. 5-10, 2021, doi: https://doi.org/10.1063/5.0043196

\section{$7 \quad$ Authors}

Isnanik Juni Fitriyah is is a lecturer at the Natural Sciences Education Study Program, Faculty of Mathematics and Natural Sciences, State University of Malang as well as a member of Indonesian Science Educators Association, Indonesia. He often works as comitee of publication (ICoMSE and Jurnal Pembelajaran Sains (JPS) (E-mail: isnanik.fitriyah.fmipa@um.ac.id).

Muhammad Fajar Marsuki is a lecturer at the Natural Sciences Education Study Program, Faculty of Mathematics and Natural Sciences, State University of Malang as well as a member of Indonesian Science Educators Association, Indonesia. He often works as comitee of publication (ICoMSE and Jurnal Pembelajaran Sains (JPS) (E-mail: muhammad.fajar.fmipa@um.ac.id).

Yessi Affriyenni is is a lecturer at the Natural Sciences Education Study Program, Faculty of Mathematics and Natural Sciences, State University of Malang as well as a member of Indonesian Science Educators Association, Indonesia. He often works as comitee of publication (ICoMSE and Jurnal Pembelajaran Sains (JPS) (E-mail: yessi. fmipa@um.ac.id).

Article submitted 2021-12-07. Resubmitted 2022-01-08. Final acceptance 2022-01-09. Final version published as submitted by the authors. 